\title{
Physicochemical, nutritional and functional properties, rate of polyphenols and flavonoids of the Stenochlaena tenuifolia (BLECHNACEAE) leaves
}

\section{RANDRIANANTENAINA Antoni ${ }^{1}{ }^{*}$, RASIDA Marie Soniah ${ }^{1}$, VOLOLONIRINA Florida Rangita ${ }^{2}$ and RAZAFIMAHEFA ${ }^{2}$}

\author{
${ }^{1}$ Food Biochemistry and Valorization of Natural Resources, Faculty of Science, \\ University of Antsiranana, BP 0-Antsiranana (201), Madagascar \\ ${ }^{2}$ Biochemistry, Microbiology and Biotechnology Applied, Faculty of Science, \\ Technology and Environment, University of Mahajanga, BP 652-Mahajanga (401), Madagascar \\ Email: antoni73@randria@gmail.com
}

*corresponding author: RANDRIANTENAINA Antoni; antoni73randria@gmail.com

\begin{abstract}
The general objective of this study is to contribute to the promotion of edible wild vegetables available in Madagascar. Its specific objective is to determine the physicochemical, nutritional and functional properties and the polyphenols and flavonoids contents of the Stenochlaena tenuifolia (BLECHNACEAE) leaves. Physical, physicochemical and biochemical methods have been used to characterize the powder from the leaves of this plant. The results obtained showed that the powder of the Stenochlaena tenuifolia leaves has a pH equal to $5.25 \pm 0.04$ and an acidity equal to $2.57 \pm 0.23 \%$. Its water and dry matter contents are respectively equal to $3.35 \pm 0.03 \%$ and $95.65 \pm 0.01 \%$. Its macronutrient content, such as proteins, crude fat and carbohydrates, expressed in grams per 100 grams of dry matter, are respectively $32.30 \pm 0.17 ; 4.27 \pm 0.06$ and $49.71 \pm 0.01$. The metabolizable energy provided by this powder (in kcal per $100 \mathrm{~g}$ ) is $292.02 \pm 0.01$. Its crude ash content is $10.35 \pm 0.04 \%$. Its mineral elements content, such as calcium, magnesium, potassium, iron, phosphorus, zinc and copper (in mg per $100 \mathrm{~g}$ ) of this powder are respectively $81.78 \pm 0.29 ; 287.15 \pm 6.60 ; 3140.59 \pm 24.64 ; 15.64 \pm 0.16 ; 540.90 \pm 7.71 ; 4.91 \pm 0.13$ and $2.85 \pm 0.03$. The potential renal acid load of this plant is -52.88 . The functional properties, such as water and oil retention capacities, the hydrophilic-lipophilic ratio and the solubility index of the powder produced are respectively $486.29 \pm 8.44 \% ; 170.00 \pm 8.16 \% ; 2.86$ and $20.36 \pm 0.20 \%$. Its total polyphenols and total flavonoids contents are respectively $457.01 \pm 0.15 \mathrm{mg}$ pyrogallol equivalent per gram of dry matter and $15.12 \pm 0.23 \mathrm{mg}$ quercetin equivalent per gram of dry matter. Therefore, this plant has important nutritional, functional and phytochemical properties. Thus, this wild leaf vegetable can be used to fight against malnutrition and especially protein-energy malnutrition which affects almost the entire population in Madagascar.
\end{abstract}

Keywords: Stenochlaena tenuifolia; leaf vegetable; physicochemical property; nutritional property; functional property; protein-energy malnutrition; Madagascar

\section{INTRODUCTION}

Stenochlaena tenuifolia is a species of fern belonging to the family of BLECHNACEAE. It is found in the coastal regions of East and Southern Africa, from Tanzania to the east coast of South Africa, and also in several localities in Madagascar [1-2].

For a long time, plants have been a major source of food for humans thanks to their richness in nutrients. Daily consumption of vegetables of the right quality and in sufficient quantity would ensure good health and prevent various chronic diseases. Their richness in certain macronutrients, trace elements, vitamins and certain phytochemicals [3] are a boon in developing countries like Madagascar where these traditional wild vegetables can help solve many public health problems [4-5].

In Madagascar, protein-energy malnutrition is the major nutritional problem and the backdrop for mortality and morbidity in children under five [6]. It results from a deficit in macronutrients and not in micronutrients [7]. The most common forms of this nutritional disease are marasmus and kwashiorkor [7]. Therefore, the consumption of plant resources rich in macronutrients and micronutrients can be popularized in Madagascar to effectively fight against these nutritional diseases.

Stenochlaena tenuifolia is a leaf vegetable much appreciated by rural populations in Madagascar. Besides its use in food, this plant is also used to treat stomach aches and gout. Its importance and nutritional characteristics are hardly documented. It is for this reason that this study was carried out. Its general objective is to contribute to the promotion of edible wild vegetables available in Madagascar. Its specific objective is to determine the physicochemical, nutritional and functional properties and the polyphenols and flavonoids contents of the leaves of this leaf vegetable. 


\section{MATERIALS AND METHODS}

i. Plant materials

The plant materials used during this study are the Stenochlaena tenuifolia (BLECHNACEAE) leaves.

\section{ii. Harvest of the leaves}

The Stenochlaena tenuifolia leaves were harvested in January 2019 in the District of Vohemar, Region of SAVA(Sambava-Antalaha-Vohemar-Andapa),

Madagascar. Only the leaves most used in human food, called young fronds, were harvested.

\section{iii. Drying of the leaves}

The harvested leaves were sorted, then cleaned. After the abduction of their main ribs, the leaves were spread on a clean braid to be dried to the shade (out of the sun), in the open air and at the ambient temperature. Drying in the shade was chosen to avoid degradation of nutrients by the sun's ultraviolet rays.

iv. Transformation of the dry leaves into powder

The dry leaves were pounded by hand in a mortar with a pestle until the powder was obtained. The latter was then sieved through a sieve to obtain a powder with a uniform particle size.

v. Determination of the physicochemical and nutritional properties of the powder produced Moisture, dry matter, crude ash, crude protein, crude fat and total carbohydrate contents were determined using the method of AOAC [8]. The reducing sugars were determined according to the method of BIPEA [9]. The $\mathrm{pH}$ and total acidity were determined according to the method of Oyewole [10] and Vasconcelos et al. [11]. The mineral element contents were determined using spectrophotometric atomic absorption (Calcium, Magnesium, Potassium, Iron, Zinc and Copper) and colorimetric (Phosphorus) methods. The metabolizable energy (expressed in $\mathrm{kcal} / 100 \mathrm{~g}$ of product) was calculated according to the method of AOAC [8] with some modifications on the specific calorific coefficients used (specific calorific coefficients of Atwater, in kcal/g of proteins, lipids and carbohydrates). The value of PRAL (Potential Renal Acid Load) was calculated according to the formula given by Remer and Manz [12] and Pamplona-Roger [13]. This formula is based on the quantity of magnesium, phosphor, calcium, potassium and proteins that the food contains.

vi. Determination of the functional properties of the powder produced

The water absorption capacity and the water solubility index were determined according to the methods employed by Philips et al. [14], Sosulski [15] and Anderson et al. [16]. The oil absorption capacity was determined according to the method of Sosulski [15]. The hydrophilic-lipophilic ratio, as defined by Njintang et al. [17], was calculated by relating the water absorption capacity to the oil absorption capacity. It is a report that permits to value affinity compared of flours for water and for oil.

vii. Determination of total polyphenols and total flavonoids contents in the powder produced

The dosage of the total polyphenols was carried out using the Folin-Ciocalteu reagent according to the method described by Singleton and Rossi [18]. The level of total flavonoids was determined according to the method described by Dehpeur et al. [19]. In this study, 70/30 (V/V) hydro-ethanolic extract was used.

\section{RESULT}

The results obtained concerning the physicochemical and nutritional properties of the powder of the Stenochlaena tenuifolia leaves are presented in TABLE 1 . These results show that this powder has a pH less than 7 and its acidity is low. They also show that the Stenochlaena tenuifolia leaves provide energy. The powder produced from these leaves are rich in dry matter and poor in water. The proteins content of these leaves is high. On the other hand, their fat content is low. The carbohydrate and crude ash contents of the powder produced are not negligible. The potassium, phosphorus, magnesium and calcium contents of these leaves are high. The other mineral elements contents (Iron, Zinc and Copper) are low. The PRAL index of the powder produced from these leaves is negative.

The functional properties of the powder produced are given in TABLE 2. According to this table, the water absorption capacity is very high. The oil absorption capacity is less than the water absorption capacity. The hydrophilic-lipophilic ratio for this powder is greater than 1. Its solubility is $20.36 \pm 0.20 \%$.

TABLE 3 gives the levels of total polyphenols and total flavonoids. This table indicates that the leaves of Stenochlaena tenuifolia contain phytochemicals.

TABLE 1: Physicochemical and nutritional properties of the powder of the Stenochlaena tenuifolia leaves

\begin{tabular}{|l|c|}
\hline Parameters & Values \\
\hline Humidity (\%) & $3.35 \pm 0.03$ \\
\hline Dry mater (\%) & $95.65 \pm 0.01$ \\
\hline pH & $5.25 \pm 0.04$ \\
\hline Total acidity (g of lactic acid/100 g; DMB) & $2.57 \pm 0.23$ \\
\hline Metabolizable energy (kcal/100 g; DMB) & $292.02 \pm 0.01$ \\
\hline Proteins (g/100 g; DMB) & $32.30 \pm 0.17$ \\
\hline Crude fat (g/100 g; DMB) & $4.27 \pm 0.06$ \\
\hline Reducing sugar (g/100 g; DMB) & $1.79 \pm 0.01$ \\
\hline Total carbohydrates (g/100 g; DMB) & $49.71 \pm 0.01$ \\
\hline Crude ash (\%; DMB) & $10,35 \pm 0,04$ \\
\hline Calcium (mg/100 g; DMB) & $81.78 \pm 0.29$ \\
\hline Magnesium (mg/100 g; DMB) & $287.15 \pm 6.60$ \\
\hline Potassium (mg/100 g; DMB) & $3140.59 \pm 24.54$ \\
\hline Iron (mg/100 g; DMB) & $15.64 \pm 0.16$ \\
\hline Phosphorus (mg/100 g; DMB) & $540.90 \pm 7.71$ \\
\hline Zinc (mg/100 g; DMB) & $4.91 \pm 0.13$ \\
\hline Copper (mg/100 g; DMB) & $2.85 \pm 0.03$ \\
\hline PRAL (meq/100 g) & -52.88 \\
\hline
\end{tabular}

Each result represents the mean \pm standard deviation of 3 independent determinations $(\mathrm{n}=3)$. The difference between the means is significant $(p \leq 0.05)$. DMB: Dry mater basis.

TABLE 2: Functional properties of the powder of the Stenochlaena tenuifolia leaves

\begin{tabular}{|l|c|}
\hline Parameters & Values \\
\hline Water retention capacity (\%) & $486.29 \pm 8.44$ \\
\hline Oil retention capacity (\%) & $170.00 \pm 8.16$ \\
\hline Hydrophilic-lipophilic ratio & 2.86 \\
\hline Solubility (\%) & $20.36 \pm 0.20$ \\
\hline
\end{tabular}

Each result represents the mean \pm standard deviation of 3 independent determinations $(n=3)$. The difference between the means is significant $(\mathrm{p} \leq 0.05)$ 
TABLE 3: Levels of total polyphenols and total flavonoids of the powder of the Stenochlaena tenuifolia leaves

\begin{tabular}{|l|c|}
\hline Parameters & Values \\
\hline Total polyphenols (mg pyrogallol eq/g; DMB) & $457.01 \pm 0.15$ \\
\hline Total flavonoids (mg quercetin eq/g; DMB) & $15.12 \pm 0.23$ \\
\hline
\end{tabular}

Each result represents the mean \pm standard deviation of 3 independent determinations $(\mathrm{n}=3)$. The difference between the means is significant $(p \leq 0.05)$. eq: equivalent.

\section{DISCUSSION}

The Stenochlaena tenuifolia leaves contain organic acids, because the $\mathrm{pH}$ of the powder of these leaves is less than 7 , but very close to 7 (Table I). However, the amount of these organic acids is low, since the acidity of the powder produced is low (Table I). Therefore, the powder of these leaves can be considered as a slightly acidic product.

The leaves of this plant can be considered as energy sources, because the energies supplied by the powder of these leaves $(292.02 \pm 0.01 \mathrm{kcal} / 100 \mathrm{~g})$ are not negligible. These energies are mainly supplied by two energy nutrients, such as proteins and carbohydrates, because the level of fat, another energy nutrient, is low $(4.27 \pm 0.06 \%)$. While, the protein and carbohydrate contents of the powder produced are high (Table I).

The protein content of the Stenochlaena tenuifolia leaves $(32.30 \pm 0.17 \%)$ is higher than the protein content $(29.70 \mathrm{~g} / 100 \mathrm{~g}$ of DM) of the Moringa oleifera (MORINGACEAE) leaves harvested in the Ex-Province of Antsiranana (Madagascar) and analyzed by Ramaroson Rakotosamimanana [20]. It is also higher than the value found by Manzo [21] on the Moringa oleifera leaves in Niger $(24.80 \%)$. It is also higher than the value obtained from black nightshade (Solanum nigrum) (Family SOLANACEAE) (29.90\%) by Ocho-Anin Atchibri et al. [22]. The difference in these values can be explained by the varietal difference. In fact, Sheetal et al. [23] noted that some tropical leafy vegetables are very rich in proteins.

The crude fat content of the powder produced is close to that found by Ramaroson Rakotosamimanana [20] in the Moringa oleifera leaves harvested in the Ex-Province of Antsiranana (Madagascar) which is equal to $5.70 \mathrm{~g} / 100 \mathrm{~g}$ of DM. In general, leaf vegetables are almost poor in fat.

The total carbohydrate content of the Stenochlaena tenuifolia leaves is higher than the result found by Fuglie [24] in the powder of the Moringa oleifera leaves which is equal to $38.20 \mathrm{~g} / 100 \mathrm{~g}$ of $\mathrm{DM}$. This difference can be explained by the varietal difference.

The crude ash content $(10.35 \pm 0.04 \%)$ is close to the result obtained by Moussa et al. [25] on the powder of the Moringa oleifera leaves collected in Senegal which is equal to $11.39 \pm 0.66 \mathrm{~g} / 100 \mathrm{~g}$ of DM. It should be noted that the crude ash content represents the quantity of mineral salts contained in a sample studied. This high value represents the large amount of mineral salts in this sample. Some literatures indicate that the rate of ashes depends a lot of the variety of the samples, of the nature of soil and the period of harvest [26-27].

The iron and magnesium levels of our sample (Table I) are higher than those obtained by Ramaroson Rakotosamimanana [20] in the Moringa oleifera leaves collected in the ExProvince of Antsiranana (Madagascar). According to this author, the levels of these two mineral elements in the Moringa oleifera leaves are respectively $8.30 \mathrm{mg} / 100 \mathrm{~g}$ of DM and $271.50 \mathrm{mg} / 100 \mathrm{~g}$ of DM. The Moringa oleifera leaves are richer in calcium $(1156.70 \mathrm{mg} / 100 \mathrm{~g}$ of DM) [20] than the Stenochlaena tenuifolia leaves. This difference can be explained by the inequality of species, harvest season and soil characteristics of harvest locations. The Stenochlaena tenuifolia leaves are rich in potassium. The potassium level in the leaves of this plant is higher than the result found by $[24,28]$ in the powder of the Moringa oleifera leaves $(1324.00 \mathrm{mg} / 100 \mathrm{~g})$. The Stenochlaena tenuifolia leaves are richer in phosphorus, zinc and copper than the powder of the Moringa oleifera leaves, because, according to Fuglie [24, 28], the levels of these mineral elements are respectively $204.00 \mathrm{mg} / 100 \mathrm{~g}$ of DM; $3.29 \mathrm{mg} / 100 \mathrm{~g}$ of $\mathrm{DM}$ and $0.57 \mathrm{mg} / 100 \mathrm{~g}$ of DM. These differences can be explained by the inequality of the samples studied.

The Stenochlaena tenuifolia leaves have an alkalizing power and generate more bases than acids, because the PRAL index of the powder of these leaves is negative. This indicates that, according to Piquet [29] and PamplonaRoger [13], these leaves help maintain the necessary balance between acids and alkalis in our body. Thus, they alleviate the work of the kidneys to eliminate the excess of acid and promote a good health. The substances contained in the leaves of this plant species are therefore able to rebalance the biochemical reaction within our body, especially in the kidney.

The functional properties provide some information on the future applications of the food formulations [30]. During this study, the functional properties of the powder produced, which were evaluated, are water retention capacity, oil retention capacity, hydrophilic-lipophilic ratio and solubility (Table II). The water retention capacity is one of the criteria that determine the sensory quality, in particular, the texture of food products [31]. Food products with a high-water retention capacity retain their friability during storage [32]. The retention of water is due to the presence of hygroscopic constituents having hydrophilic groups. For the powder of the Stenochlaena tenuifolia leaves, these hygroscopic constituents are essentially carbohydrates (having free hydroxyl groups: $\mathrm{OH}$ ) and proteins (having hydrophilic groups: $=\mathrm{CO},-\mathrm{NH}-$ ), because this powder is rich into these compounds (Table I). By the presence of these hydrophilic groups, these compounds can, therefore, bind with water molecules via hydrogen bonds. This powder can, therefore, be hold the sensory quality and their friability is retained during storage.

The powder of the Stenochlaena tenuifolia leaves is also capable to keep oil. It indicates that this powder closes substances having non-polar chains such as lipids. Moreover, this powder contains lipids, although their level is low (Table I). The oil retention capacity is an important property in feed formulation. It would act as a flavor retainer and mouth feel enhancer; it gives an indication of the retention capacity of flour flavor [33-34].

The hydrophilic-lipophilic ratio is a ratio which makes it possible to evaluate the comparative affinity of flours for water and for oil [35]. During this study, the value found (2.86), which is greater than 1, indicates that Stenochlaena tenuifolia powder has more affinity with water than with oil.

The powder of the Stenochlaena tenuifolia leaves has particles and/or substances which are soluble in water, since its solubility is not negligible $(20.36 \pm 0.20 \%)$. In fact, it contains carbohydrates and minerals, all of which are water-soluble compounds.

The powder of the Stenochlaena tenuifolia leaves contains phytochemicals, which are real natural medicines belonging to plants [36]. 
Among the phytochemicals present in this powder, there are polyphenols and flavonoids (Table III). These compounds are phytochemicals exerting an antioxidant action [36-38]. They are, therefore, natural antioxidants. It should be noted that antioxidants are substances that have the ability to prevent the oxidation of various types of molecules in our body such as: lipoproteins, nucleic acids and free radicals [38]. Free radicals are compounds that are continuously generated by the human body due to its own metabolic activity or formed as a result of infections, stress and pollution [39-40]. These free radicals can donate electrons; they are thus endowed with pro-oxidant action [39]. These are then the most harmful oxidizing agents and they are aggressive molecules capable of damaging our own molecules [38]. Then, our body needs antioxidants in order to neutralize these free radicals. Thus, they have been shown to be useful in combating many diseases such as: arteriosclerosis, cancer, myocardial infarction, immunosuppression, cellular aging and intoxication by chemicals or unhealthy foods [36, 38]. Thanks to the presence of polyphenols and flavonoids, which are powerful antioxidants, the consumption of the Stenochlaena tenuifolia leaves prevents the oxidation of various types of molecules in our body and, therefore, improves our health or ensures the proper functioning of our organization.

The Stenochlaena tenuifolia leaves are richer in polyphenols than the Moringa oleifera leaves because, according to Belhi et al. [41], the total polyphenol content of the Moringa oleifera leaves is $236.50 \mathrm{mg}$ gallic acid equivalent per gram of dry matter. On the other hand, the Moringa oleifera leaves are richer in flavonoids than those of Stenochlaena tenuifolia, since, according to Belhi et al. [41], the level of flavonoids in the Moringa oleifera leaves is $77.33 \mathrm{mg}$ quercetin equivalent per gram of dry matter. These differences may be due to the varietal difference, the difference in the control used during the assay and the uneven season of sample collection.

\section{CONCLUSION}

The results of this study showed that the Stenochlaena tenuifolia leaves are sources of protein, mineral salts and polyphenols. Thus, they can be used for the prevention and correction of malnutrition due to their exceptional nutritional qualities. Then, the powder of the leaves of this plant can be used to model a high-quality infant food. The consumption of this leaf vegetable and its derived products can be popularized. Therefore, this will ensure the proper functioning of the human body thanks to the presence of phytochemicals, such as polyphenols and flavonoids, which are all powerful natural antioxidants.

\section{REFERENCES}

[1] Holttum A. (1971). Monographie du genre Stenochlaena tenuifolia. Fern J, 61(3), Pp. 119-123.

[2] Van der Burg, W. J. (2004). Stenochlaena tenuifolia (Desv.) T.Moore. [Internet] Record from PROTA4U. Grubben, G.J.H. \& Denton, O.A. (Editors). PROTA (Plant Resources of Tropical Africa/Ressources végétales de l'Afrique tropicale), Wageningen, Netherlands.

[3] Sanclemente, T., Marques-Lopes, I., Fajó-Pascual, M., Cofán, M., Jarauta, E., Ros, E., Puzo, J. and GarcíaOtín, A. L. (2011). Naturally-occurring phytosterols in the usual diet influence cholesterol metabolism in healthy subjects. Nutrition, Metabolism \& Cardiovascular Diseases, 22(10), Pp. 849-55.

[4] Atchibri, A. L. O-A., Soro, L.C., Kouame, C., Agbo, E. A. et Kouadio, K. K. A. (2012). Valeur nutritionnelle des légumes feuilles consommés en Côte d'Ivoire. Int. J.
Biol. Chem. Sci, 6(1), Pp.128-135.

[5] Acho, C. F., Zoue, L. T., Akpa, E.E., Yapo, V. G. and Niamke, S. L. (2014). Leafy vegetables consumed in Southern Côte d'Ivoire: a source of high value nutrients. Journal of Animal \& Plant Sciences, 20 (3), Pp. 3159-3170.

[6] Jeannoda V., Ralison Ch., Ramanitrera C., Ramaharobandro C., Randrianaivo D. et Randrianarivony A. R. (1997). La situation alimentaire et nutritionnelle à Madagascar: Stratégie nationale de sécurité alimentaire et de nutrition, 134p.

[7] Latham M. C. (2001). Partie III: - Les troubles de la nutrition. Chapitre 12: La malnutrition protéinoénergétique. In: FAO: La nutrition dans les pays en développement. New York, Etas Unis, Pp. 135-154.

[8] AOAC (2005). Official method of analysis of the Association of official Analytical Chemist, 5th ad. AOAC Press, Arlington, Virginia, USA.

[9] BIPEA. (1978). Recueil des méthodes d'analyse des communautés européenne, Pp. 857-860.

[10] Oyewole, O. B. (1990). Optimization of cassava fermentation for fufu production: effects of single starter cultures. Journal Applied Bacteriology, 68, Pp. 49-54.

[11] Vasconcelos, A. T., Twiddy, D. R., Westby, A. and Reilly, P. J. A. (1990). Detoxification of cassava during gari preparation. International Journal of Food Science and Technology, 25, Pp. 198-203.

[12] Remer, T. and Manz, F. (1995). Potential Renal Acid Load of Foods and its Influence on Urine $\mathrm{pH}$. Journal of the American Dietetic Association, 95(7), Pp. 791797.

[13] Pamplona-Roger, G. D. (2016). Santé par les boissons. Jus, smoothies et infusion: Guide pratique pour votre bienêtre, Première Edition. Colmenar Viejo, Madrid (Espagne): Editions Safeliz S. L, Pp.268-271. (Collection: Vie et Santé).

[14] Philips, R. D., Chinnan, M. S., Brach, A. L., Miller, J., and McWatters, K. H. (1988). Effects of pretreatment on functional and nutritional properties of cowpea meal. Journal of Food Science, 53(3), Pp. 805-809.

[15] Sosulski, F. W. (1962). The centrifuge method for determining flour absorption in hard red spring wheat. Cereal Chemistry, 39, Pp.344-350.

[16] Anderson, R. A., Conway, H. F., Pfeiffer, V. F., and Griffin, E. L. (1969). Roll and extrusion cooking of grain sorghum grits. Cereal Science Today, 14, Pp.372-375.

[17] Njintang, Y. N., Mbofung, C. M. F., and Waldron, K. W. (2001). In vitro protein digestibility and physicochemical properties of dry red bean (Phaseolus vulgaris) flour: effect of processing and incorporation of soybean and cowpea flour. Journal of Agriculture and Food Chemistry, 49, Pp. 2465-2471.

[18] Singleton, V. L., Rossi, J. A. (1965). Colorimetry of total phenolics with phosphomolybdicphosphotungstic acid reagents. American Journal of Enology and Viticulture, 16, Pp. 144-15 
[19] Dehpour, A. A., Ibrahimzadeh, A. M., Seyed Fazel, N. and Seyed Mohammad, N. (2009). - Antioxydant activity of the methanol extract of Ferula assafoetida and its essential oil composition. Grasas Y Aceites, 60, Pp. 405-412.

[20] Ramaroson Rakotosamimanana, V. (2014). Étude des pratiques et croyances alimentaires pour comprendre la malnutrition à Madagascar. Intérêt de l'introduction de feuilles de Moringa oleifera. Thèse Doctorat. Soutenue à Dijon le 2 octobre 2014. Université de Bourgogne, 166p.

[21] Manzo, M. L. (2016). Composition de la poudre des feuilles sèches de Moringa oleifera dans trois régions du Niger, 16 (4), Pp. 11432-11442.

[22] Ocho-anin Atchibri, A. L., Soro, L. C., Kouame, C., Agbo, E. A. et Kouadio, K. K. A. (2012). Valeur nutritionnelle des légumes feuilles consommés en Côte d'Ivoire. Int. J. Biol. Chem. Sci, 6(1), Pp. 128-135.

[23] Sheetal Gupta, A., Lakshmi, J., Manjunath, M. N. and Prakash, J. (2005). Analysis of nutrient and antinutrient content of underutilized green leafy vegetables. LWT, 38, Pp. 339-345.

[24] Fuglie, L. J. (2002a). Les nombreux usages du Moringa (7-28). In: L'arbre de la vie: Les multiples usages du Moringa. Dakar: CTA et CWS, 177p.

[25] Moussa, N., Salimata, W., Nicole, D., Amadou, T. G. et Rokhaya, D. G. (2007). Valeur nutritionnelle du Moringa oleifera, étude de la biodisponibilité du fer, effet de l'enrichissement de divers' plats traditionnels Sénégalais avec la poudre des feuilles. African Journal of food Agriculture Nutrition and Development, 7(3), Pp. 1-17.

[26] Baiyeri, K.P. (2000). Effect of nitrogen fertilization on mineral concentration in plantain (Musa sp AAB) fruit peel and pulp at unripe and ripe stages. Plant Product Research Journal, 5, Pp. 38-43.

[27] Pacheco-Delahaye, E., Maldonado, R., Pérez, E. and Schroeder, M. (2008). Production and characterization of unripe plantain (Musa paradisiaca) flours. INCI, 33(4), Pp. 290-296.

[28] Fuglie, L.J. (2002b). Le Moringa dans la médecine traditionnelle (141-148), In: L'arbre de la vie: Les multiples usages du Moringa. -Wageningen: CTA; Dakar: CWS, 177p.

[29] Piquet F. (2012). Guide de l'équilibre acide-base: Plus, de 800 aliments classés selon leur pouvoir acidifiant ou basifiant. - Thiérry Souccar Editions \& La Nutrition.fr, Vergère.

[30] Hermansson A. M. and Svegmark K. (1996). Developments in the understanding of starch functionality. Trends in Food Science and Technology, 7, Pp. 345-353.

[31] Selmane, D. (2010). Étude de l'extraction des protéines de coproduits d'abattage et de leurvalorisation comme ingrédients fonctionnels, Université Blaise PascalClermont Ferrand II.

[32] Boye, J., Aksay, S., Roufik, S., Ribéreau, S., Mondor, M., Farnworth, E., and Rajamohamed, S. (2010). Comparison of the functional properties of pea, chickpea and lentil protein concentrates processed using ultrafiltration and isoelectric precipitation techniques. Food Research International, 43(2), Pp. 537-546.

[33] Kaushal, P., Kumar, V. and Sharma, H. K. (2012). Comparative study of physicochemical, functional, antinutritional and pasting properties of taro (Colocasia esculenta), rice (Oryza sativa) flour, pigeon pea (Cajanus cajan) flour and their blends. LWT. Food Science and Technology, 48, Pp.59-68.

[34] Yadahally, N., Sreerama., Vadakkoot, B., Sashikala., Vishwas, M., Pratape. and Vasudeva S. (2012). Nutrients and antinutrients in cowpea and horse gram flours in comparison to chickpea flour: Evaluation of their flour functionality. Food Chemistry, 131, Pp.462-468.

[35] Medoua Nama G. J. M. (2005). Potentiels nutritionnel et technologique des tubercules durcis de l'igname Dioscorea dumetorum (Kunth) Pax: Etude du durcissement post-récolte et des conditions de transformation des tubercules durcis en farine. Autre. Université de Ngaoundéré, 2005. Français. Fftel00011268

[36] Pamplona-Roger G. D. (2010). Croquet la vie! Des aliments qui guérissent et qui préviennent. Première Edition. Madrid (Espagne): Safeliz S. L., p. 80. (Collection Nouveau Style de Vie).

[37] Achat S. (2013). Polyphénols de l'alimentation: extraction, pouvoir antioxydant et interactions avec des ions métalliques. - Thèse de Doctorat en Sciences alimentaires: A. Mira de Bejaia: Faculté des Sciences de la Nature et de la Vie; Avignon et des Pays de Vaucluse: Ecole Doctorale 536 - Avignon, 211p.

[38] Pamplona-Roger G. D. (2013a). Guide des aliments et de leur pouvoir curatif: Traité de bromatologie et diétothérapie. - Première partie: La science des aliments. - Huitième édition en français de l'édition originale en espagnole. - E-28770 Colmenar Viejo, Madrid, Espagne : Editorial Safeliz, S. L. Volume 1, Pp. 348-361; 382-411. (Bibliothèque éducation et santé).

[39] Pamplona-Roger G. D. (2013b). Guide des aliments et de leur pouvoir curatif:: Traité de bromatologie et diétothérapie. - Première partie: La science des aliments. - Huitième édition en français de l'édition originale en espagnole. - E-28770 Colmenar Viejo, Madrid, Espagne : Editorial Safeliz, S. L. - Volume 2, p. $264-274$; 360-365; 378-387. - (Bibliothèque éducation et santé).

[40] Kouchadé S. A., Adjatin A. R., Adomou A. C., Dassou H. G. et Akoègninou A. (2017). Phytochimiques des plantes médicinales utilisées dans la prise en charge des maladies infantiles au Sud-Bénin. European Scientific Journal, 13(3), Pp. 1857-7431.

[41] Belhi, M., Selmi, H., Tibaoui, G., Aloui, F., Jedidi, S. and Rouissi. H. (2018). Propriétés chimiques et facteurs anti-nutritionnelles de la Moringa oleifera. Journal of new sciences, Agriculture and Biotechnology, CIRS, (11), Pp.3338-3342 